\title{
The Effectiveness of Petobo Temporary Shelter
}

\author{
Asiana Rahmawatia,", Mohammad Mochsen ${ }^{\mathrm{b}}$, Abdul Mufti Radja ${ }^{\mathrm{c}}$ \\ aDepartment of Architecture, Faculty of Engineering, Hasanuddin University, Makassar. Indonesia. Email: asianarahmawati@pm.me \\ ${ }^{b}$ Department of Architecture, Faculty of Engineering, Hasanuddin University, Makassar, Indonesia. Email: sirmochsen@gmail.com \\ 'Department of Architecture, Faculty of Engineering, Hasanuddin University, Makassar, Indonesia. Email: muftiradja@ gmail.com
}

\begin{abstract}
Temporary shelter (huntara) is one of the government's solutions in undertaking victims after a disaster. Shelter of Petobo is one of the temporary shelters built by the government in the aftermath of the disaster in Palu City in September 28th, 2018. Petobo shelter was built in October and occupied in December. This shelter has a capacity of 70 units. 1 unit of the shelter is measured $26.4 \mathrm{~m} \times 12 \mathrm{~m}$, it consists of 12 rooms, 4 bathrooms, 4 toilets, a laundry room, and a shared kitchen. The shelter consists of 840 room cubicles with room sizes of $3.6 \mathrm{~m} \times 4.8 \mathrm{~m}$. After being occupied, some residents said that the shelter they lived in was very small, with family members of more than 3 people, the space for occupants was very limited so that some residents made changes to their residential units. This study evaluates Petobo shelter with BNPB and UNHCR Standards, and examines occupant perceptions about the effectiveness of Petobo shelter in terms of physical building requirements which consist of safety, health, comfort, and convenience. This research was conducted in Palu City, Central Sulawesi. The type of this research is evaluation, using survey methods to measure the value of several variables. The data obtained were analyzed using descriptive statistical techniques. The results of this study indicate that the Petobo shelter is in accordance with BNPB and UNHCR standards, but according to the occupants' perception it is less effective in terms of the physical requirements of the building, which consists of safety, health, comfort, and convenience as a post-disaster refugee residence.
\end{abstract}

Keywords: Conformity; effectiveness; perceptions of occupants; temporary shelter

\section{Introduction}

According to the Law of the Republic of Indonesia Number 24 of 2007, Disaster is an event that threatens and disrupts people's lives caused by natural and non-natural factors, resulting in fatalities, environmental damage, property losses, and psychological impacts [1]. On September 28, 2018 an earthquake occurred in Palu City and its surroundings. The impact of the earthquake resulted in many deaths, as well as destroyed buildings and infrastructure [2]. Besides having to lose family and relatives, they also have to move or flee to a safe place. This has become a sensitive issue for the government in dealing with disasters.

One of the government's solutions in dealing with disasters is to build temporary shelters. The development of shelters is intended as one of the recovery efforts that bridges the transition period between the emergency response phase and the reconstruction period [3]. This is expected to alleviate the suffering of victims of disasters in the city of Palu. The shelters in Palu City were built by the Ministry of PUPR. The shelter can become a standard for those who want to assist in the provision of shelter in Palu and its surroundings [4]. The Indonesian Institute of Sciences (LIPI) revealed, so far the Indonesian

\footnotetext{
${ }^{*}$ Corresponding author. Tel.: +6282290490332

Perumahan Nurul Baidah D1/5,

Gowa, Sulawesi Selatan
}

government does not yet have a standard for the shelter for victims of natural disasters. Petobo shelter is one of the shelters in Palu City. This shelter is \pm 10 Ha wide. Petobo shelter was built in October 2018, and began to be occupied in December 2018. Petobo shelter has a capacity of 70 units. 1 unit of shelter measuring $26.4 \mathrm{~m} \mathrm{x} 12 \mathrm{~m}$, consisting of 12 rooms, and supporting facilities such as 4 bathrooms, 4 toilet, laundry room, and shared kitchen. Petobo shelter consists of 840 rooms that can accommodate 4200 people, where 1 household gets 1 room with a maximum capacity of 5 people.

The residents of the Petobo shelter said that the shelter they lived in was very small, the size of each room is only $3.6 \mathrm{~m} \times 4.8 \mathrm{~m}$ with family members of more than 3 people, the space was very limited, and this was one of the problems in the Petobo shelter. Another problem is that many residents of the shelters make changes in their housing units, by adding more spaces independently. Furthermore, some of the residents of the shelter also build other huts around Petobo shelter, and the unit they got is only used as storage for goods. Based on these phenomena, the problem can be formulated, namely: how the effectiveness of the Petobo shelter as a place for postdisaster refugees in Palu City according to residents' perceptions. 


\section{Literature Review}

\subsection{Temporary shelter}

Temporary shelters are different from emergency shelters and permanent shelters. Temporary shelters are impermanent shelters and do not have to meet all the criteria of permanent shelters, but on the other hand, temporary shelters must also meet the minimum living needs of their users for one-two years [5]. Thus, specific criteria are needed in designing the basic concepts of temporary shelter. Due to it is in term of temporary, the method of construction and design of this shelter must be designed effectively and efficiently.

\subsection{Feasibility of temporary shelter}

It must be ensured that temporary shelter aid is appropriate to accomplish the needs of affected communities and the occupancy standards. The concept of "ineligibility of shelter" can be applied to all types of shelters, from emergency shelters to permanent shelters. It is important to remember that shelter is a process. A residence is considered appropriate only if the residents have access to basic services such as education and health, as well as the opportunity to undertake livelihood activities in the settlement or community. According to the Ministry of Social, to determine what is feasible or not, there are several important points that must be considered, namely safe from further risks, environmentally friendly, appropriate resilience, in accordance to local culture, appropriate facilities, access to services, and in accordance to climate [6].

\subsection{Effectiveness of temporary shelter}

Effectiveness is one concept that has a very important meaning, but the reality is difficult to define with certainty. The reason is there are many concepts related to the sense of effectiveness. The word 'effective' comes from English, which is effective, that means successful or something done successfully. According to Hidayat [7] mentioning effectiveness is as a measure that states how far the target (quantity, quality, and time) has been achieved.

According to Kelman in Ero [8], effectiveness is part of the evaluation, to test and assess whether the undertaken policy actions (programs) produce impacts which achieves the main goals. In other words, effectiveness can also be a measure of success in achieving goals. The development process generally starts from the planning, implementation, and evaluation stages, so effectiveness is included in the evaluation stage. The shelter was supposed to be built as a place to evacuate affected communities after the disaster, and can help ease their burden, thus they can live properly. The perception of residents living in temporary shelters determines the effectiveness of the shelter as a post-disaster refugee's site.

In the Law of the Republic of Indonesia number 28 of 2002 concerning building construction [9], each building must accomplish administrative and technical requirements in accordance with the function of the

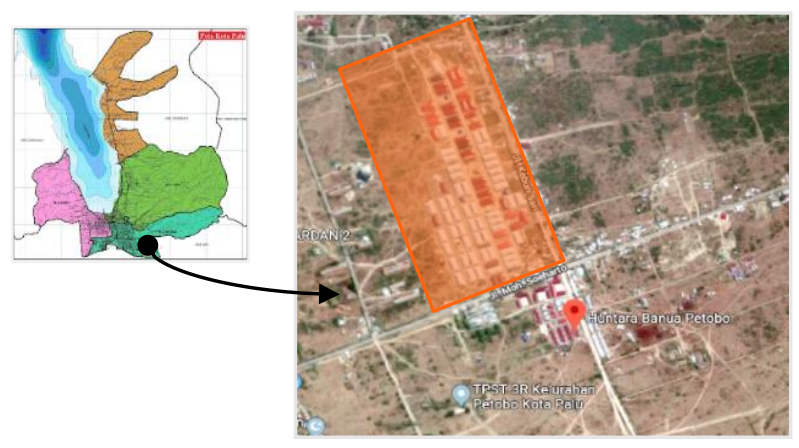

Figure 1. Location of the shelters in the city of Palu [10]

building. Temporary shelter serves for after-disaster refugees. In order for temporary shelters to be functioned effectively, according to the Law of the Republic of Indonesia number 28 of 2002, temporary shelters must achieve the building technical requirements of safety, health, security, and convenience.

\section{Research Methods}

\subsection{Research sites}

The research location is a place to conduct research activities to obtain data from respondents. The research location (see Fig. 1) is located in Petobo shelter located on Jalan Kebun Sari, Village of Petobo, Sub-district of South Palu, Palu, and Central Sulawesi Province.

\subsection{Types of research}

The type of this research is quantitative with 2 methods, namely evaluation and survey. To answer the appropriateness of Petobo shelter with BNPB and UNHCR standards, the method used is evaluation. Weiss argues that evaluation research is applied research, which is a systematic way to find out the effectiveness of a program, policy, or other object under study if it is compared to the objectives or standards set [11].

\subsection{Population and sampling techniques}

The target population is the head of the family or family members who are considered to be able to represent to answer questions from researchers. The total population of this study was 840 households. In this study, researcher used simple random sampling because the population is considered homogeneous, and sampling members of the population are carried out randomly without regarding to strata. To determine the number of samples, based on existing population, the sample of this study used Yamane formula [12]. The number of samples needed to answer the effectiveness of temporary shelters in the Petobo shelter is 89 households.

\subsection{Data collection technique}

To have this research more focused, and based on the problem formulation that has been described, the data collection techniques used namely: observation, study of literature, documentation, and questionnaires. 


\subsection{Data analysis technique}

Data analysis is classifying data based on variables and types of respondents, tabulating data based on variables from all respondents, and doing calculations to answer the problem formulation [12]. Data analysis techniques in this study using statistics.

Analysis of the efficacy data in question is an evaluation to test and assess whether Petobo shelter has an impact in accordance with the main objectives, where the purpose of the shelter as a post-disaster refugee site. To measure this, it is used a level to describe how the shelter building units provided for disaster victims. The data obtained in the form of respondents' answers which are then categorized by score using Likert scale measurement [12], where (3) = effective, (2) = less effective, (1) ineffective. Next, calculate the percentage and score of each using a formulation.

\section{Discussion}

Petobo shelter can be said to be effective if the shelter can achieve the building technical requirements. The perception of the residents of the shelter determines the effectiveness of the shelter as a post-disaster refugee site. There are 4 variables to measure the effectiveness of temporary shelter, among others.

\subsection{Safety}

Safety in question in this study is the safety requirements of shelter building includes building location, building structure shelters ability to withstand loads during an earthquake, and security in shelters in tackling a fire hazard.

Safety, in this study, refers to the requirements of the shelter building including the location of the building, the ability of the building structure to withstand the load during an earthquake, and security in the shelter in overcoming the fire hazard. Residents' perceptions to assess the location of the shelter, can be seen in the results of a questionnaire as shown in Fig. 2.

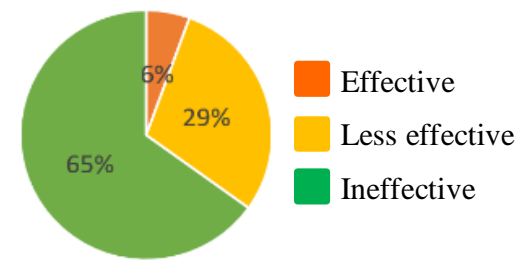

Figure 2. Result of the questionnaire of the shelter's location

Table 1. The result of the assessment of the shelter location based on the residents' perception

\begin{tabular}{|c|c|c|c|c|c|}
\hline \multicolumn{3}{|c|}{ Assessment } & \multirow{2}{*}{ respondents } & \multirow{2}{*}{$\begin{array}{c}\text { Category } \\
(\%)\end{array}$} & \multirow{2}{*}{$\begin{array}{c}\text { variable } \\
\text { score }\end{array}$} \\
\hline shelter locations & Category & Weight & & & \\
\hline $\begin{array}{l}\text { Feel safe in the } \\
\text { shelter location }\end{array}$ & Effective & 3 & 5 & 5.6 & 15 \\
\hline $\begin{array}{c}\text { Feel less safe and } \\
\text { have no other } \\
\text { choice }\end{array}$ & Less effective & 2 & 26 & 29.3 & 52 \\
\hline $\begin{array}{c}\text { Feel insecure and } \\
\text { fear of } \\
\text { forthcoming } \\
\text { disaster }\end{array}$ & Ineffective & 1 & 58 & 65.1 & 58 \\
\hline \multicolumn{3}{|c|}{ amount } & 89 & 100 & 125 \\
\hline \multicolumn{5}{|c|}{ The effectiveness of variable $=125 /(89 \times 3) \times 100 \%$} & $47 \%$ \\
\hline
\end{tabular}

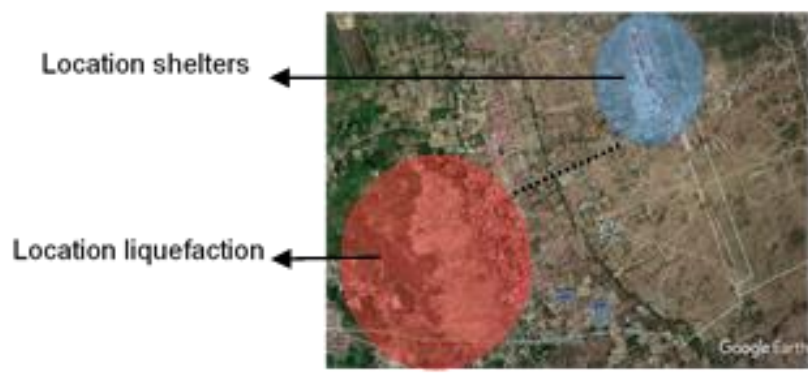

Figure 3. The distance to the location of shelters Petobo liquefaction

From Table 1 above, the residents of Petobo shelter answered that the location of the shelter is currently unsafe. This is because the location of the shelter is only \pm $1 \mathrm{~km}$ from the former location of liquefaction (see Fig. 3), the residents of the shelter are still traumatized by the disaster that befell them. Many residents want to move out from this location, but they have no choice but to stay in the shelter.

The ability of building structures to withstand loads during an earthquake is one of the building's safety requirements. The perception of residents is needed to assess the capability of the building structure of a shelter. The results of the questionnaire can be seen in Fig. 4 .

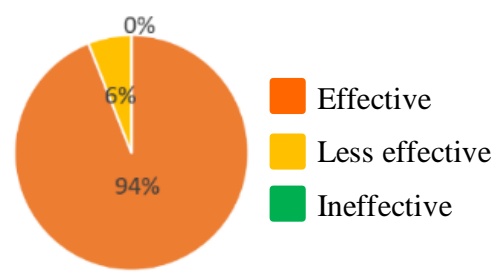

Figure 4. The results of the questionnaire capability building structure

Table 2. Results of analysis o the shelter structure ability assesment based on the residents' perception

\begin{tabular}{|c|c|c|c|c|c|}
\hline \multicolumn{3}{|c|}{ Assessment } & \multirow[b]{2}{*}{ respondents } & \multirow[b]{2}{*}{$\begin{array}{c}\text { Category } \\
(\%)\end{array}$} & \multirow[b]{2}{*}{$\begin{array}{c}\text { Score } \\
\text { Variable }\end{array}$} \\
\hline $\begin{array}{c}\text { Shelter Structures } \\
\text { Capability }\end{array}$ & Category & Weight & & & \\
\hline $\begin{array}{l}\text { There was no } \\
\text { damage to the } \\
\text { structure during } \\
\text { the stay and } \\
\text { earthquakes }\end{array}$ & Effective & 3 & 84 & 94.3 & 249 \\
\hline $\begin{array}{l}\text { There is a non- } \\
\text { structural damage } \\
\text { during the stay } \\
\text { and earthquakes }\end{array}$ & $\begin{array}{l}\text { Less } \\
\text { effective }\end{array}$ & 2 & 5 & 5.7 & 10 \\
\hline $\begin{array}{l}\text { damage to the } \\
\text { structure so that } \\
\text { the shelters } \\
\text { uninhabitable }\end{array}$ & Ineffective & 1 & 0 & 0 & 0 \\
\hline \multicolumn{3}{|c|}{ Amount } & 89 & 100 & 259 \\
\hline \multicolumn{5}{|c|}{ The effectiveness of variable $=259 /(89 \times 3) \times 100 \%$} & $98 \%$ \\
\hline
\end{tabular}

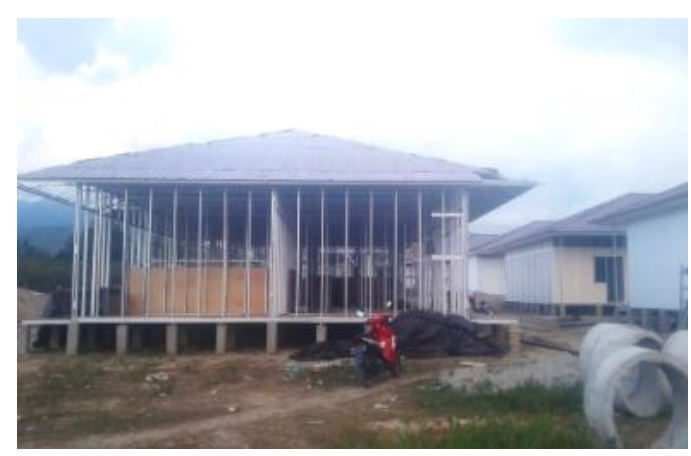

Figure 5. Mild steel structure in Petobo shelter 


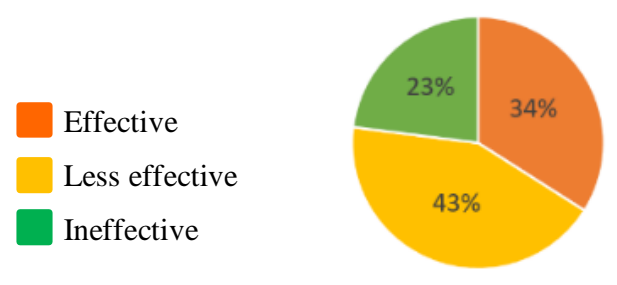

Figure 6. Results of the questionnaire of fire safety

Table 3. Result of the analysis of fire safety assessment based on the residents' perception

\begin{tabular}{|c|c|c|c|c|c|}
\hline \multicolumn{3}{|c|}{ Assessment } & \multirow[b]{2}{*}{ respondents } & \multirow{2}{*}{$\begin{array}{c}\text { Category } \\
(\%)\end{array}$} & \multirow{2}{*}{$\begin{array}{c}\text { Score } \\
\text { Variable }\end{array}$} \\
\hline $\begin{array}{l}\text { Distance of } \\
\text { Firebreak }\end{array}$ & Category & Weight & & & \\
\hline $\begin{array}{l}\text { Distance between } \\
\text { residential } \pm 8 \mathrm{~m}\end{array}$ & Effective & 3 & 30 & 33.7 & 90 \\
\hline $\begin{array}{l}\text { Distance between } \\
\text { residential } \pm 5 \mathrm{~m}\end{array}$ & $\begin{array}{c}\text { Less } \\
\text { effective }\end{array}$ & 2 & 38 & 42.6 & 76 \\
\hline $\begin{array}{l}\text { Distance between } \\
\text { the adjacent } \\
\text { residential } \pm 3 \mathrm{~m}\end{array}$ & Ineffective & 1 & 21 & 23.7 & 21 \\
\hline \multicolumn{3}{|c|}{ Amount } & 89 & 100 & 187 \\
\hline
\end{tabular}

From Table 2, most of the residents of the shelter said that the ability of shelter building structure is effective enough to withstand the load. Petobo shelter structure using mild steel with disassembly models (see Fig. 5). When an earthquake occurs, the structure remains sturdy and only a fraction of the shelters which suffered from minor damage, but the shelter is still habitable.

Fire safety in shelters, in this study, is the distance between residences there is a firebreak (vacant land to prevent fire expansion). Residents' perceptions are needed to assess security in the shelters in dealing with fire hazards. The results of the questionnaire can be seen in Fig. 6.

From Table 3, the residents of the shelter answered that the fire safety in the shelter was quite effective. This is because the distance between the residences is varied. Petobo shelter site was designed using a grid layout with a rectangular area separated by a road, where the width of the road is 8 meters (see Fig. 7). While respondents who answered less effective and ineffective because their shelter units are facing each other and the distance is close to each other, it is about 3-5 meters (see Fig. 8).

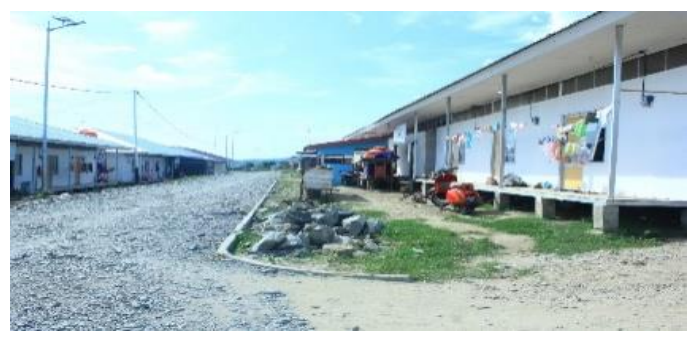

Figure 7. Shelter Petobo separated by road

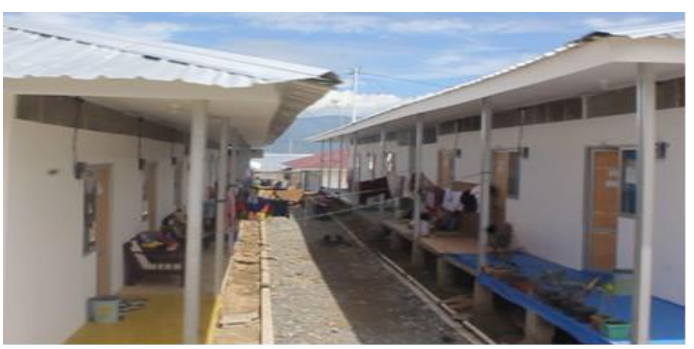

Figure 8. Petobo that face each other shelters
Table 4. Safety of shelter building of Petobo

\begin{tabular}{|c|c|c|c|}
\hline No. & $\begin{array}{c}\text { Indicators of Safety of Shelter } \\
\text { Building }\end{array}$ & $\begin{array}{c}\text { level of } \\
\text { Effectiveness } \\
(\%)\end{array}$ & Category \\
\hline 1 & Shelter Location & $47 \%$ & $\begin{array}{c}\text { Less } \\
\text { effective }\end{array}$ \\
\hline 2 & $\begin{array}{c}\text { The ability of the structure from } \\
\text { earthquake }\end{array}$ & $98 \%$ & Effective \\
\hline 3 & fire safety & $70 \%$ & Effective \\
\hline & Average Effectiveness & $72 \%$ & Effective \\
\hline
\end{tabular}

The results of analysis of the effectiveness of the shelter building Assessment Summary based on the resident's perception are shown in Table 4 .

\subsection{Health}

Health, in this study, is referred to the requirements of the shelter building, including the, lighting system, and sanitation. Residents' perceptions are needed to assess the availability of openings in the shelter unit as air exchange. The results of the questionnaire can be seen in Fig. 9.

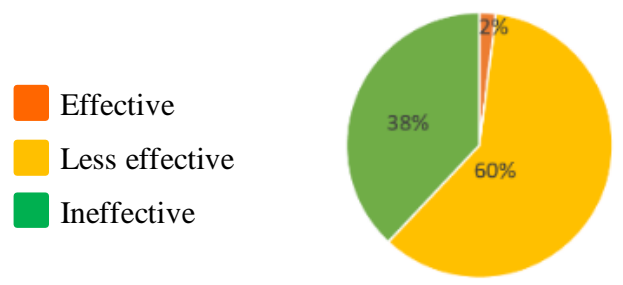

Figure 9. Results of air conditioning system questionnaire

Table 5. Results of analysis of air conditioning availability assessment in the shelter based on theresidents' perception

\begin{tabular}{|c|c|c|c|c|c|}
\hline \multicolumn{3}{|c|}{ Assessment } & \multirow[b]{2}{*}{ respondents } & \multirow[b]{2}{*}{$\begin{array}{c}\text { Category } \\
(\%)\end{array}$} & \multirow[b]{2}{*}{$\begin{array}{c}\text { variable } \\
\text { score }\end{array}$} \\
\hline $\begin{array}{l}\text { Availability of Air } \\
\text { Conditioning }\end{array}$ & Category & Weight & & & \\
\hline $\begin{array}{c}\text { Achieve the needs } \\
\text { of residents }\end{array}$ & Effective & 3 & 2 & 2.2 & 6 \\
\hline $\begin{array}{c}\text { Less achieve the } \\
\text { needs of residents }\end{array}$ & $\begin{array}{c}\text { Less } \\
\text { effective }\end{array}$ & 2 & 53 & 59.6 & 106 \\
\hline \multirow[t]{2}{*}{$\begin{array}{c}\text { Does not achieve } \\
\text { the needs of } \\
\text { residents }\end{array}$} & Ineffective & 1 & 34 & 38.2 & 34 \\
\hline & ount & & 89 & 100 & 146 \\
\hline \multicolumn{5}{|c|}{ The effectiveness of variable $=146 /(89 \times 3) \times 100 \%$} & $55 \%$ \\
\hline
\end{tabular}

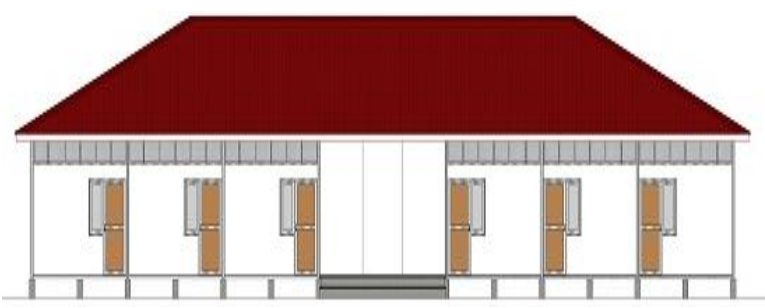

Figure 10. View of Shelter building of Petobo

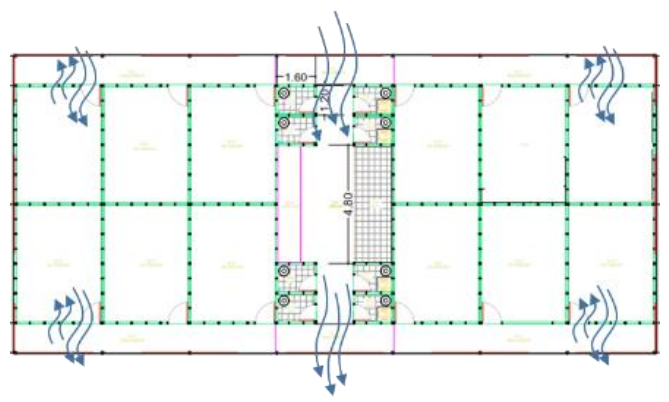

Figure 11. Air exchange in shelter units of Petobo 
From Table 5, it can be seen that the residents of the shelter said that the availability of openings in the shelter units are less effective for air exchange. This is due to the design of openings layout such as doors, windows, and vents at the shelter units (see Fig. 10). Occupancy openings are located on one side of the room, where openings on the same side make the air come in the room through the same side as the air is out. This makes the air exchange in the residential units less than optimal.

Air exchange at supporting facilities located in the central part of the shelter is also less effective (see Fig. 11 ), because the positions of the opposite openings are the same size. This makes the air exchange inside lower. Besides, the location of the toilet and public bathroom adjacent to the residential unit makes the residents less comfortable because of the smell of the toilet.

Lighting systems in the building must have openings for natural lighting, and have a light source for artificial lighting. The residents' perception is needed to assess the availability of lighting in the shelter building. The results of the questionnaire can be seen in Fig. 12.

From Table 6, the residents of the shelter answered that the availability og lighting system at Petobo shelter is effective. This is due to the fact that residents of the shelter feel that they had enough natural light enter the shelter unit through the openings such as doors, windows, and vents. Some residents in the shelter also answered less effective because the light entering the room is excessive, causing glare, but there are treatments of the residents to minimize glare in buildings (see Fig. 13) by using curtains, and some are using canopy with improvised material.

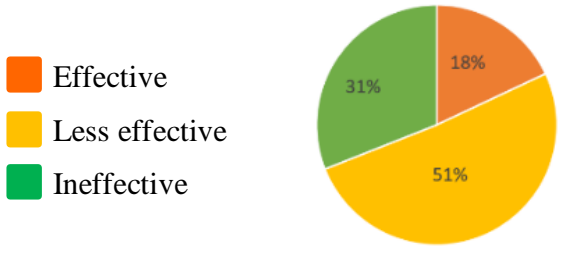

Figure 12. Results of the lighting system questionnaire

Table 6. The Results of analysis of the lighting availability assessment based on residents' perception

\begin{tabular}{|c|c|c|c|c|c|}
\hline \multicolumn{3}{|c|}{ Assessment } & \multirow[b]{2}{*}{ frequency } & \multirow{2}{*}{$\begin{array}{c}\text { Category } \\
(\%)\end{array}$} & \multirow{2}{*}{$\begin{array}{c}\text { variable } \\
\text { score }\end{array}$} \\
\hline $\begin{array}{c}\text { Availability of } \\
\text { Lighting }\end{array}$ & Category & Weight & & & \\
\hline $\begin{array}{l}\text { Achieve needs of } \\
\text { residents }\end{array}$ & Effective & 3 & 56 & 62.9 & 168 \\
\hline $\begin{array}{l}\text { Less achieve the } \\
\text { needs of residents }\end{array}$ & $\begin{array}{c}\text { Less } \\
\text { effective }\end{array}$ & 2 & 22 & 24.7 & 44 \\
\hline $\begin{array}{l}\text { Does not meet the } \\
\text { needs of residents }\end{array}$ & Ineffective & 1 & 11 & 12.4 & 11 \\
\hline \multicolumn{3}{|c|}{ amount } & 89 & 100 & 223 \\
\hline \multicolumn{5}{|c|}{ The effectiveness of variable $=223 /(89 \times 3) \times 100 \%$} & $83 \%$ \\
\hline
\end{tabular}

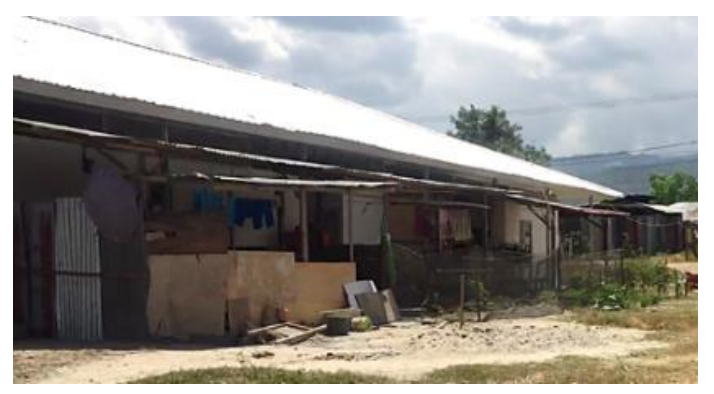

Figure 13. Minimize the light entering the shelter unit

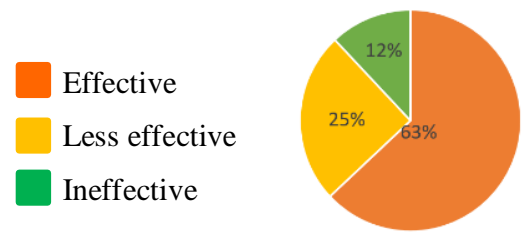

Figure 14. The results of the sanitation system questionnaire

Table 7. Result of analysis of the sanitation system assessment based on residents' perceptions

\begin{tabular}{|c|c|c|c|c|c|}
\hline \multicolumn{3}{|c|}{ Assessment } & \multirow[b]{2}{*}{ respondents } & \multirow[b]{2}{*}{$\begin{array}{c}\text { Category } \\
(\%)\end{array}$} & \multirow[b]{2}{*}{$\begin{array}{c}\text { variable } \\
\text { score }\end{array}$} \\
\hline $\begin{array}{c}\text { Availability } \\
\text { of sanitation } \\
\text { in shelters }\end{array}$ & Category & Weight & & & \\
\hline $\begin{array}{l}\text { avhieve the } \\
\text { availability } \\
\text { of sanitation }\end{array}$ & Effective & 3 & 16 & 18 & 48 \\
\hline $\begin{array}{c}\text { Less achieve } \\
\text { availability } \\
\text { of sanitation }\end{array}$ & $\begin{array}{c}\text { Less } \\
\text { effective }\end{array}$ & 2 & 45 & 50.6 & 90 \\
\hline $\begin{array}{c}\text { Does not } \\
\text { achieve the } \\
\text { availability } \\
\text { of sanitation }\end{array}$ & Ineffective & 1 & 28 & 31.5 & 28 \\
\hline & Amount & & 89 & 100 & 166 \\
\hline
\end{tabular}

Building health also includes sanitation. To reach the sanitation system requirements in the buildings, the shelter must be equipped with a clean water supply system, sewage and garbage system. Residents' perceptions are needed to assess the availability of sanitation system. The results of the questionnaire can be seen in Fig. 14

Based on the Table 7, residents of the shelter answered that the availability of sanitation system in Petobo shelter is less effective for the needs of residents. This is due to the sanitation system in the shelter, namely the availability of clean water for bathing and drinking, and the waste water disposal system is very lack. The source of clean water in Petobo shelter is a wellbore, which uses an indirect system and a solar cell (see Fig. 15).

As for the waste water disposal system in Petobo shelter, not all the units in Petobo shelter have drainage. Besides, the liquid and solid waste disposals are put together towards septitank (see Fig. 16), thus some septitanks in the units are overflowed and leak.

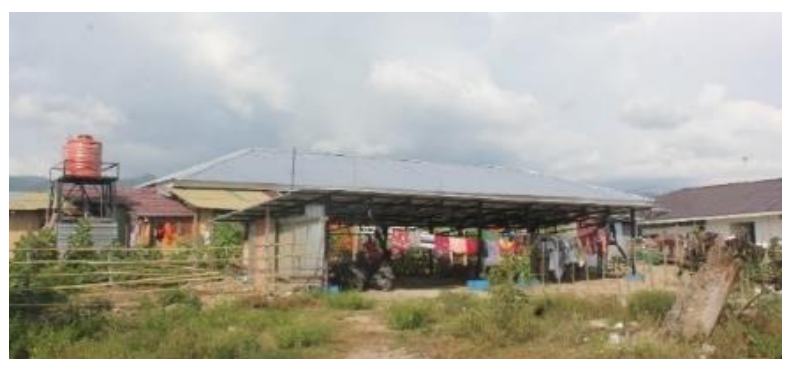

Figure 15. Solar cell in shelter of Petobo
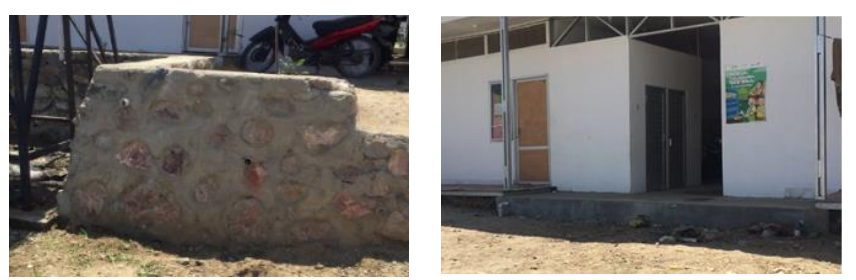

Figure 16. The liquid waste disposal pipe 
Table 8. Health building of Petobo shelters

\begin{tabular}{cccc}
\hline No. & $\begin{array}{c}\text { Indicators of Shelter Building } \\
\text { Health }\end{array}$ & $\begin{array}{c}\text { level of } \\
\text { Effectiveness } \\
(\boldsymbol{\%})\end{array}$ & Category \\
\hline $\mathbf{1}$ & Air conditioning system & $55 \%$ & $\begin{array}{c}\text { Less } \\
\text { effective }\end{array}$ \\
$\mathbf{2}$ & lighting system & $83 \%$ & $\begin{array}{c}\text { Effective } \\
\text { Less } \\
\text { effective }\end{array}$ \\
\hline $\mathbf{3}$ & Sanitation system & $62 \%$ & $\begin{array}{c}\text { Less } \\
\text { effective }\end{array}$ \\
\hline
\end{tabular}

The assessment of the health effectiveness of a building based on the residents' perception is shown in Table 8.

\subsection{Convenience}

In this study, convenience means the comfort of the space, the availability of space to fulfill the needs of the residents, the comfort of privacy in carrying out activities in the shelter building, and the level of comfort is determined by a condition that does not result to the user and the function of the building being disturbed by vibration or noise both from within the building and its environment. The convenience of space in the shelter must consider the dimensions of space, and the number of users. The results of the questionnaire can be seen in Fig. 17.

Based on the Table 9, the residents of the shelter answered that the space comfort in Petobo shelter is less effective. This is because the area of the shelter units is not proportional for the number of residents. On average residents who have 3 or more family members feel uncomfortable staying in the shelter. Many residents add more spaces to their residential units (see Fig. 18), with remains of liquefaction materials.

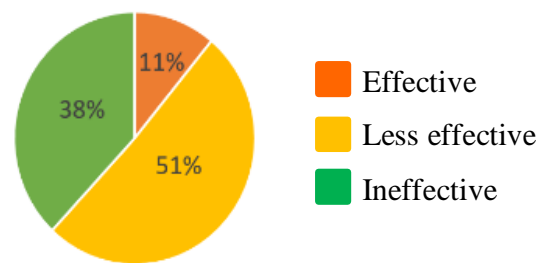

Figure 17. The results of the questionnaire comfort space

Table 9. Results of the analysis of comfort ratings based on perception occupant space

\begin{tabular}{|c|c|c|c|c|c|}
\hline \multicolumn{3}{|c|}{ Assessment } & \multirow{2}{*}{ respondents } & \multirow{2}{*}{$\begin{array}{c}\text { Category } \\
(\%)\end{array}$} & \multirow{2}{*}{$\begin{array}{c}\text { variable } \\
\text { score }\end{array}$} \\
\hline Comfort space & Category & Weight & & & \\
\hline Space suit guests' & Effective & 3 & 10 & 11.2 & 30 \\
\hline $\begin{array}{l}\text { Less space suit } \\
\text { guests' }\end{array}$ & $\begin{array}{l}\text { Less } \\
\text { effective }\end{array}$ & 2 & 45 & 50.6 & 90 \\
\hline $\begin{array}{l}\text { Does not meet the } \\
\text { comfort of the } \\
\text { space }\end{array}$ & Ineffective & 1 & 34 & 38.2 & 34 \\
\hline \multicolumn{3}{|c|}{ mount } & 89 & 100 & 154 \\
\hline
\end{tabular}

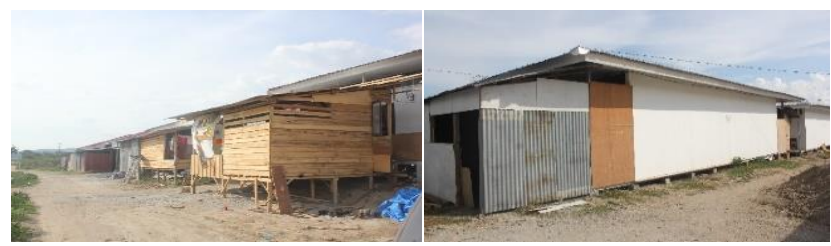

Figure 18. The addition of space in the units of Petobo shelter
Effective

Less effective

Ineffective

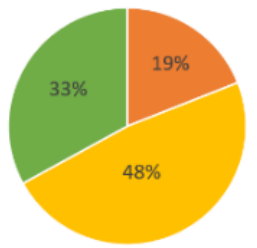

Figure 19. Results of the availability of space questionnaire

Table 10. Result of analysis of space availability assessment based on the residents' perception

\begin{tabular}{|c|c|c|c|c|c|}
\hline \multicolumn{3}{|c|}{ Assessment } & \multirow[b]{2}{*}{ respondents } & \multirow[b]{2}{*}{$\begin{array}{c}\text { Category } \\
(\%)\end{array}$} & \multirow[b]{2}{*}{$\begin{array}{l}\text { variable } \\
\text { score }\end{array}$} \\
\hline $\begin{array}{l}\text { The availability of } \\
\text { space in shelters }\end{array}$ & Category & Weight & & & \\
\hline $\begin{array}{l}\text { Achieve the needs } \\
\text { of residents }\end{array}$ & Effective & 3 & 17 & 19.1 & 51 \\
\hline $\begin{array}{l}\text { Less achieve the } \\
\text { needs of residents }\end{array}$ & $\begin{array}{c}\text { Less } \\
\text { effective }\end{array}$ & 2 & 43 & 48.3 & 86 \\
\hline $\begin{array}{l}\text { Does not achieve } \\
\text { the needs of } \\
\text { residents }\end{array}$ & Ineffective & 1 & 29 & 32.6 & 29 \\
\hline \multicolumn{3}{|c|}{ Amount } & 89 & 100 & 166 \\
\hline
\end{tabular}

The requirements of the comfort at the shelter are also influenced by the availability of space. The results of the questionnaire of 89 respondents can be seen in Fig. 19

Residents of the shelter answered in Table 10 that the availability of space in Petobo shelter is not effective. For the availability of bathrooms, toilets, and laundry rooms in residential areas, residents already feel quite effective. Whereas, for shared kitchens, many residents do not use it. The reason is because the kitchen provided is small for users of 12 families. Then, the kitchen that is not used according to its function, eventually, is converted into residents parking (see Fig. 20).

Privacy is also one of the comfort requirements at the shelter. The privacy, in this study, is referred to the reviewed from the layout of the room. The results of the questionnaire can be seen in Fig. 21.

From Table 11, the residents of the shelter answered that the privacy in Petobo shelter is ineffective or nonexistent. This is due to the absence of a public toilet distribution for men and women. Thus, it is vulnerable to sexual harassment in public facilities in the shelter unit. In addition, many residents limit their occupancy as a form of privacy (see Fig. 22).
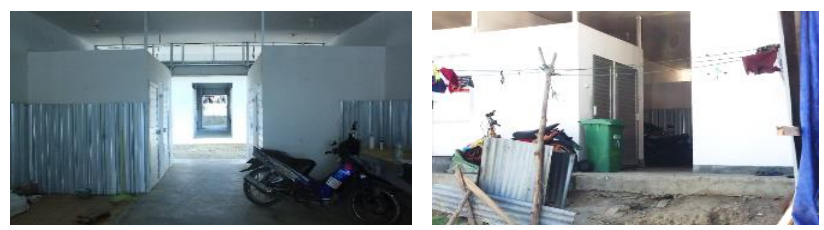

Figure 20. Transformation of kitchen function in Petobo Shelter

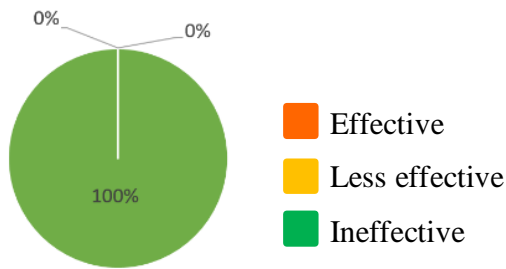

Figure 21. The results of the questionnaire privacy space 
Table 11. Result of analysis of the privacy space assessment based on the residents' perception

\begin{tabular}{|c|c|c|c|c|c|}
\hline \multicolumn{3}{|c|}{ Assessment } & \multirow[b]{2}{*}{ respondents } & \multirow[b]{2}{*}{$\begin{array}{c}\text { Category } \\
(\%)\end{array}$} & \multirow[b]{2}{*}{$\begin{array}{c}\text { variable } \\
\text { score }\end{array}$} \\
\hline $\begin{array}{l}\text { Privacy in } \\
\text { shelters }\end{array}$ & Category & Weight & & & \\
\hline $\begin{array}{l}\text { Achieve privacy } \\
\text { of residents }\end{array}$ & Effective & 3 & 0 & 0 & 0 \\
\hline $\begin{array}{l}\text { Less achieve the } \\
\text { privacy of } \\
\text { residents }\end{array}$ & $\begin{array}{l}\text { Less } \\
\text { effective }\end{array}$ & 2 & 0 & 0 & 0 \\
\hline \multirow[t]{2}{*}{$\begin{array}{l}\text { Does not achieve } \\
\text { the privacy of } \\
\text { residents }\end{array}$} & Ineffective & 1 & 89 & 100 & 89 \\
\hline & ount & & 89 & 100 & 89 \\
\hline \multicolumn{5}{|c|}{ The effectiveness of variable $=89 /(89 \times 3) \times 100 \%$} & $33 \%$ \\
\hline
\end{tabular}

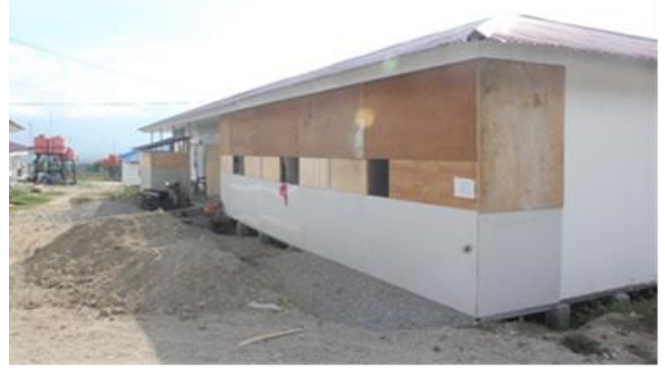

Figure 22. Privacy in Petobo shelter

Convenience at the shelter is also determined by a situation that does not result in the user being disturbed by vibrations or noise arising either inside or outside the building. The results of the questionnaire can be seen in Fig. 23.

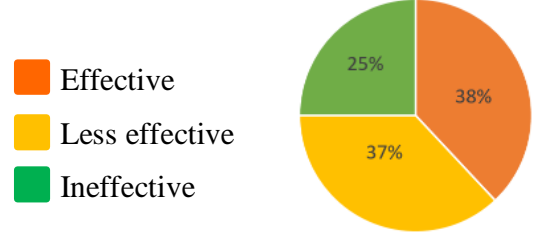

Figure 23. The results of the questionnaire noise

Table 12. Result of analysis of noise based on the residents' perception

\begin{tabular}{|c|c|c|c|c|c|}
\hline \multicolumn{3}{|c|}{ Assessment } & \multirow[t]{2}{*}{ frequency } & \multirow{2}{*}{$\begin{array}{c}\text { Category } \\
(\%)\end{array}$} & \multirow{2}{*}{$\begin{array}{c}\text { variable } \\
\text { score }\end{array}$} \\
\hline Noise & Category & Weight & & & \\
\hline $\begin{array}{l}\text { Not noisy in at } \\
\text { shelter }\end{array}$ & Effective & 3 & 0 & 0 & 0 \\
\hline $\begin{array}{l}\text { Less noisy at } \\
\text { shelterr }\end{array}$ & $\begin{array}{c}\text { Less } \\
\text { effective }\end{array}$ & 2 & 40 & 44.9 & 80 \\
\hline \multirow[t]{3}{*}{$\begin{array}{c}\begin{array}{c}\text { Very noisy at } \\
\text { shelter }\end{array} \\
\end{array}$} & Ineffective & 1 & 49 & 55.1 & 49 \\
\hline & \multicolumn{2}{|c|}{ Amount } & 89 & 100 & 166 \\
\hline & \multicolumn{4}{|c|}{ The effectiveness of variable $=166 /(89 \times 3) \times 100 \%$} & $48 \%$ \\
\hline
\end{tabular}

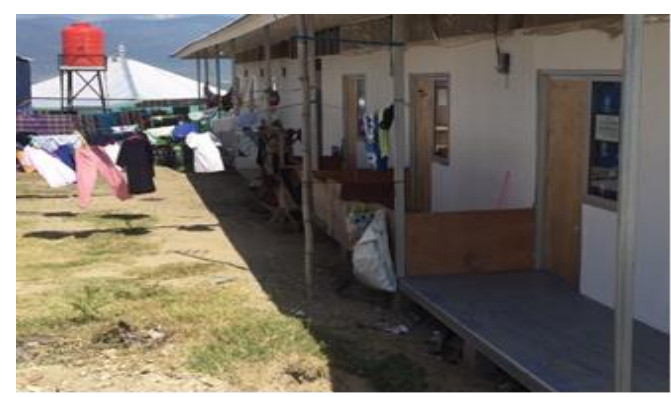

Figure 24. Build up the the boundaries at the residence unit Petobo Shelter
Table 13. comfort of the shelter building of Petobo

\begin{tabular}{|c|c|c|c|}
\hline No. & $\begin{array}{c}\text { Indicators of comfort of Shelter } \\
\text { Building }\end{array}$ & $\begin{array}{c}\text { Level of } \\
\text { Effectiveness } \\
(\%)\end{array}$ & category \\
\hline 1 & Comfort of space & $57 \%$ & $\begin{array}{l}\text { Less } \\
\text { effective }\end{array}$ \\
\hline 2 & The availability of space & $62 \%$ & $\begin{array}{l}\text { Less } \\
\text { effective }\end{array}$ \\
\hline 3 & Privacy & $33 \%$ & $\begin{array}{l}\text { Less } \\
\text { effective }\end{array}$ \\
\hline 4 & Noise & $48 \%$ & $\begin{array}{l}\text { Less } \\
\text { effective }\end{array}$ \\
\hline & Average & $50 \%$ & $\begin{array}{l}\text { Less } \\
\text { effective }\end{array}$ \\
\hline
\end{tabular}

From Table 12, it can be said that the residents feel very noisy at the shelter of Petobo. This is because the covering material of the wall and floor do not muffle the sound. That is why if people walk or children run around the shelter unit, it will cause noise. One of the methods used by the residents to reduce noise is to build up boundaries between their residences and others (see Fig. 24). The Effectiveness of comfort of shelter building based on the residents' perception is shown in Table 13.

\subsection{Easiness}

Easiness, in this study, refers to the requirements for the simplicity of building of Petobo shelter, including the ease of connection to, from, and inside the buildings, availability of facilities, accessibility that is easy, safe, and convenient, including for persons with disabilities and the elderly. Residents' perceptions are needed to assess circulation in the shelter. The results of the questionnaire can be seen in Fig. 25.

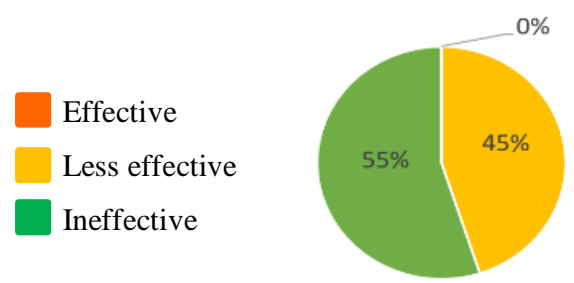

Figure 25. Result of the Ease of relationship to, from, and within building questionnaire

Table 14. Result of the analysis of ease of relationship to, from, and within the building based on the residents' perception

\begin{tabular}{|c|c|c|c|c|c|}
\hline \multicolumn{3}{|c|}{ Assessment } & \multirow{2}{*}{ respondents } & \multirow{2}{*}{$\begin{array}{c}\text { Category } \\
(\%)\end{array}$} & \multirow{2}{*}{$\begin{array}{c}\text { variable } \\
\text { score }\end{array}$} \\
\hline Circulation & Category & Weight & & & \\
\hline $\begin{array}{l}\text { Easy, safe and } \\
\text { convenient }\end{array}$ & Effective & 3 & 34 & 38.2 & 102 \\
\hline $\begin{array}{c}\text { Less easy, safe } \\
\text { and } \\
\text { convenient }\end{array}$ & Less effective & 2 & 33 & 37.1 & 66 \\
\hline $\begin{array}{c}\text { uneasy, unsafe } \\
\text { and } \\
\text { inconvenient }\end{array}$ & Ineffective & 1 & 22 & 24.7 & 22 \\
\hline \multirow{2}{*}{\multicolumn{5}{|c|}{$\begin{array}{cc}\text { Amount } & 89 \\
\text { The effectiveness of variable }=190 /(89 \times 3) \times 100 \%\end{array}$}} & 190 \\
\hline & & & & & $71 \%$ \\
\hline
\end{tabular}

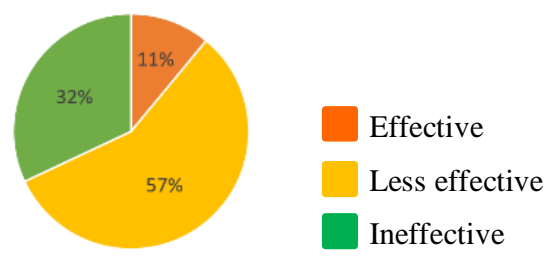

Figure 26. The results of the questionnaire facilities and accessibility 
From Table 14, it can be concluded that most of the residents of the shelter answered that the ease of contact to, from, and inside the building at Petobo shelter is effective. The requirements of building facilities also include the provision of facilities and accessibility that are easy, safe, and cconvenient, including for people with disabilities and the elderly. The perception of residents is needed to assess the facilities and accessibility that is easy, safe, and convenient at the shelter. The results of the questionnaire can be seen in Fig. 26.

Table 15. Result of analysis of facilities and accessibility assessment based on the residents' perception

\begin{tabular}{|c|c|c|c|c|c|}
\hline \multicolumn{3}{|c|}{ Assessment } & \multirow[t]{2}{*}{ Respondents } & \multirow[t]{2}{*}{$\begin{array}{c}\text { Category } \\
(\%)\end{array}$} & \multirow[t]{2}{*}{$\begin{array}{c}\text { variable } \\
\text { score }\end{array}$} \\
\hline $\begin{array}{c}\text { Ease of the building } \\
\text { for people with } \\
\text { disabilities and } \\
\text { elderly }\end{array}$ & Category & Weight & & & \\
\hline Achieve the easiness & Effective & 3 & 10 & 11.2 & 30 \\
\hline $\begin{array}{l}\text { Lessachieve the } \\
\text { easiness }\end{array}$ & Less effective & 2 & 51 & 57.3 & 102 \\
\hline $\begin{array}{c}\text { Does not achieve the } \\
\text { easiness }\end{array}$ & Ineffective & 1 & 28 & 31.5 & 28 \\
\hline \multicolumn{3}{|c|}{ Amount } & 89 & 100 & 160 \\
\hline \multicolumn{5}{|c|}{ of variable $=160 /(89 \times 3) \times 100 \%$} & $60 \%$ \\
\hline
\end{tabular}

From Table 15, most of the residents of the shelter answered the ease of accessibility for people with disabilities and the elderly in Petobo shelter is less effective. This is due to the lack of access for people with disabilities. Some residents provide their own stairs to help ascend to the residential unit (see Fig. 27).

The effectiveness of the convenience of building shelter based on the residents' perception is shown in Table 16. Based on the analysis and discussion above about the effectiveness of temporary shelter in terms of the physical requirements of the building, including safety, health, comfort, and convenience, it is summarized as follows shown in Table 17.

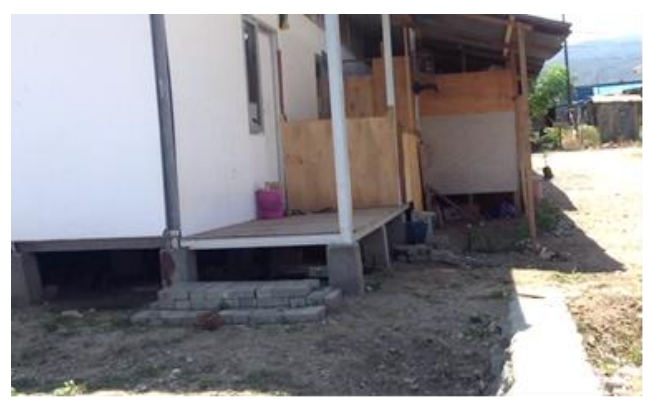

Figure 27. Stairs to help ascend to the residential units

Table 16. Convenience of shelter building of Petobo

\begin{tabular}{cccc}
\hline No. & $\begin{array}{c}\text { Indicators of convenience } \\
\text { of the building }\end{array}$ & $\begin{array}{c}\text { level of } \\
\text { effectiveness }(\%)\end{array}$ & category \\
\hline 1 & accessibility & $71 \%$ & $\begin{array}{c}\text { Less } \\
\text { effective } \\
\text { Less } \\
\text { effective }\end{array}$ \\
\hline 2 & provision of facilities & $60 \%$ & less effective \\
\hline
\end{tabular}

Table 17. Comfort of shelter building of Petobo

\begin{tabular}{cccc}
\hline No. & $\begin{array}{c}\text { Effectiveness indicator } \\
\text { shelter }\end{array}$ & $\begin{array}{c}\text { Level of } \\
\text { effectiveness (\%) }\end{array}$ & Category \\
\hline $\mathbf{1}$ & Safety & 72 & Effective \\
$\mathbf{2}$ & Health & 67 & Less effective \\
$\mathbf{3}$ & Convenience & 50 & Less effective \\
$\mathbf{4}$ & Easiness & 66 & Less effective \\
\hline Average Index 255/4 x 100\% & $62 \%$ & Less effective \\
\hline
\end{tabular}

From the analysis and discussion in the table above, it can be concluded that the effectiveness of shelter Petobo terms of the perception of shelter occupants to safety, health, comfort, and convenience by $62 \%$, where the category is less effective. So the temporary dwelling Petobo less effective as a container or a refugee after the disaster because does not meet the physical requirements of the building. Less effective in terms of safety because of the location of shelters Petobo. In terms of health is less effective because the system penghawaan in shelters less and also the management of liquid and solid wastes are put together. In terms of comfort, less effective due to lack of space makes discomfort, so that residents add space in their dwelling units. In addition layout of the rooms and lack of privacy between spaces. In terms of convenience.

From the analysis and discussion in the table above, it can be concluded that the effectiveness of Petobo shelter based on the residents' perception in terms of safety, health, concenience, and easiness is $62 \%$, which is less effective. Therefore, the temporary shelter of Petobo is less effective as a place for refugees after a disaster because it does not achieve the physical requirements of the building. In term of safety is less effective because of the location of Petobo shelter. In term of health, it is less effective because of the lack of adequate ventilation in the shelter unit and also the integrated management of liquid and solid waste disposal system. In term of convenience, it is less effective due to the lack of space creating inconvenience, so that residents add more spaces to their residential units. Besides, the layout of the room affects on the absence of privacy between spaces. In term of easines, it is less effective because there are no facilities that can support people with disabilities and the elderly such as stairs.

\section{Conclusions and Suggestion}

\subsection{Conclusions}

The effectiveness of Petobo shelter based on the the residents' perception is $62 \%$, which is in less effective category. Thus, the temporary shelter of Petobo is less effective as a place for refugees after a disaster because it does not achieve the physical requirements of buildings such as safety, health, convenience, and easiness. In term of safety, it is less effective because of the location of Petobo shelter. In term of health, it is less effective because of the lack of adequate ventilation in the shelter and also the integrated management of liquid and solid waste disposal system. In term of convenience, it is less effective due to the lack of space creating inconvenience, so that residents add more spaces in their residential units. Besides, the layout of the room affects the lack of privacy betweesn spaces. In term esiness, it is less effective because there are no facilities that can support people with disabilities and the elderly such as stairs.

\subsection{Suggestions}

Based on the results of the study, suggestions that can be made to improve the effectiveness of temporary shelter are as follows: 
a. It needs further evaluation related to the location of the shelters that are adjacent to the liquefaction location.

b. It is better for having privacy between sexes for the convenience of residents, and to reduce the potential for crime at the shelter.

c. It is necessary to plant vegetation at the shelter area to reduce heat and filter out dust.

d. Although the temporary shelter is only inhabited in a short period of time, it is necessary to pay attention to the need for clean water sources, liquid and solid waste storage, supporting facilities such as parking, security posts, and guardrail.

e. Temporary shelter design needs to pay attention to the convenience for elderly residents and people with disabilities.

\section{References}

[1] House of Representative of Indonesia Republic, Law of the Republic of Indonesia Number 24 on Disaster Management. 2007. (in Bahasa)

[2] BNPB, "Loss and Damage Disaster Impacts in Central Sulawesi Reached 13.82 Trillion Rupiah," 2018. [Online]. Available: https://www.bnpb.go.id/. [Accessed: 15-Jun-2019].

[3] F. S. Affisa, "Effectiveness of Temporary Shelter Region as PostDisaster Recovery Media Merapi Refugees 2010 (Case Study on Temporary Shelter Region Plosokerep, Gondangpusung,
Banjarsari and Gondanglegi)," Graduate School of UGM, 2013. (in Bahasa)

[4] Pu-net, "The Ministry of PUPR Targets 699 shelters Unit Completed End of February 2019," 2019. [Online]. Available: https://www.pu.go.id/berita. [Accessed: 17-Aug-2019]. (In Bahasa)

[5] A. J. Forouzandeh, M. Hosseini, and M. Sadeghzadeh, "Guidelines for Design of Temporary Shelters After Earthquakes Based On Community Participation," in The 14th World Conference on Earthquake Engineering (WCEE), 2008.

[6] Social Ministry of the Republic Indonesia, Free Shelter for Humanity, Asean. Jakarta: Fabian Prideaux, 2019.

[7] W. A. Tantu, "Evaluation of Damage to Roads and Road Maintenance Management Effectiveness on Line Traffic West South Sulawesi (Case Study Roads Pare-Pare Boundary South West)," Graduate School of Hasanuddin University, 2009. (in Bahasa)

[8] Ero, "Effectiveness Analysis pembagunan Konaweha River Bridge Toll-Mowila Wawolemo Southeast Sulawesi Province Vicinity of Improved Accessibility," Graduate School of Hasanuddin University, 2008. (in Bahasa)

[9] House of Representative of Indonesia Republic, Law of the Republic of Indonesia Number 28 of 2002 on Building. Jakarta.

[10] Palu City Statistics Center, "Maps of Palu City," 2018. [Online]. Available: https://palukota.bps.go.id/. [Accessed: 17-Aug-2019].

[11] Sugiyono, Research Methods Evaluation (Approach Quantitative, Qualitative, and Combination). Bandung: Alfabeta, 2018. (in Bahasa)

[12] Sugiyono, Research Methods Combined (Mixed Methods). Bandung: Alfabeta, 2018. (in Bahasa) 